\title{
Reasons for high school students dropping out of physical education classes Razones por las que los estudiantes de secundaria abandonan las clases de educación física
}

Willer Soares Maffei, Mayra Grava Moraes, Silvia Regina Cassan Bonome Vanzelli, Debora Navarro Kato, Talita Fabiana Roque Silva, Gleyce Soares Reis, Carlos Eduardo Lopes Verardi

Sao Paulo State University (Brasil)

\begin{abstract}
This research sought to analyze the dynamics of physical education classes in the 3rd year of high school and to recognize the profile of the classes and the involvement of students, understanding the reasons that lead them to drop out. This is a descriptive and cross-sectional study. A questionnaire was used to gather data on the participation of 517 high school students in physical education classes in the 3rd year of high school in state public schools in the interior of São Paulo. For the analysis of the information, a descriptive analysis and content analysis were used. The initial results showed that $44 \%$ of the sample had some barrier that prevents them from taking classes. Of this percentage, $74.6 \%$ were girls, who were the majority, and who answered open questions about non-participation. It is concluded that approximately half of the participating students, mainly girls, participate little, or do not participate in physical education classes, this result being related to the methodology and the selection of content developed by the teacher. The role of physical education classes is to serve all students, respecting their differences, stimulating their potential to contribute so that they are proactive, critical, and autonomous in relation to their health and quality of life.
\end{abstract}

Keywords: motivation, high school, school physical education, learning, dropout.

Resumen. Esta investigación buscó analizar la dinámica de las clases de Educación Física en el tercer año de la escuela secundaria y reconocer el perfil de las clases y la participación de los estudiantes, entendiendo las razones que los llevaron a abandonar la escuela. Se trata de un estudio descriptivo y transversal. Se utilizó un cuestionario para recopilar datos sobre la participación de 517 estudiantes de secundaria en las clases de educación física en el tercer año de secundaria en las escuelas públicas estatales del interior de São Paulo. Para el análisis de la información se utilizó un análisis descriptivo y un análisis de contenido. Los resultados iniciales mostraron que el $44 \%$ de la muestra tiene alguna barrera que les impide tomar clases. De este porcentaje, el 74,6\% son niñas, que fueron la mayoría que respondieron preguntas abiertas sobre la no participación. Se concluye que aproximadamente la mitad de los estudiantes participantes, principalmente niñas, participan poco o no participan en las clases de Educación Física, este resultado está relacionado con la metodología y la selección de contenido desarrollado por el maestro. Por lo tanto, el papel de las clases de educación física es servir a todos los estudiantes, respetando sus diferencias, estimulando su potencial de contribuir para que sean proactivos, críticos y autónomos en relación con su salud y calidad de vida.

Palabras clave: motivación, bachillerato, educación física escolar, aprendizaje, deserción.

\section{Introduction}

Physical education in high school has the main function of exploring the different body practices of different cultural groups, leading students to experience and reflect on such cultures in a way that values, appreciates, and transforms them, thus stimulating intellectual curiosity. These practices must be deepened in the different stages of schooling and thus, the student must feel challenged to reflect on them, assuming them into their routine, finding an active lifestyle in order to maintain their own health and those around them, taking knowledge beyond the school walls, giving new meaning to public spaces, and exercising their role in the community (Brasil, 2017).

Among the components of the basic curriculum, physical education is configured as that which that arouses great interest on the part of students, which may be related to the physical space in which activities are developed, with different characteristics from conventional classrooms, along with sensations of freedom experienced through movement as the main axis, and its directions as games, playing, and competitiveness related to the component (Martins \& Santos, 2013). On the other hand, it is observed that the practice

Fecha recepción: 26-06-20. Fecha de aceptación: 22-09-20

Mayra Grava Moraes

mayra.grava@unesp.br of physical activity from the perspective of the adolescent in high school, brings specificities related to the age group, as it arouses some different interests in these individuals, normally focused on the manifestations of culture and movement such as hip hop, capoeira, martial arts, weight training and other elements that are not always present in everyday life and school curriculum (Cedran, Martins \& Ligeiro, 2016).

In this sense, it is also observed that the practice of physical activity tends to decrease as students advance their school years, thus demonstrating less interest in sports and physical practice in general, resulting in the evasion of classes. (Colunga-Rodriguez, Ángel-Gonzalez, Vázquez-Juárez, Vázquez-Colunga, Castellanos-Ángeles, Colunga-Rodriguez, \& Picazo, 2020; Rodríguez-Rodríguez, Gatica, de la Rosa \& Flores, 2017). According Peykari et al. (2015), the large number of tasks and commitments in high school, as well as the feeling of wasting time practicing physical exercise, are factors that can strengthen the non-participation of adolescents in physical activities.

In addition, studies indicate that in this age group there is a significant growth in sedentary behaviors, caused by the excessive use of technologies, which makes screen-based activities such as the use of cell phones, televisions and video games, more attractive and present in the daily lives of young (Lucena, Cheng, Cavalcante, Silva \& Farias Junior, 2015; Christofaro, Andrade, Mesas, Fernandes \& Farias Junior, 2016; Munaro, Silva \& Lopes, 2016). These data 
corroborate the research carried out by Lourenço, Zanetti, Amorim, Mota e Mendes (2018), who identified in the survey carried out with high school students, that sedentary behavior prevails in eight out of ten adolescents, and may be present in isolation (access to only one media device) or aggregate (access to television, video games and computer)

Another relevant factor pointed out by the literature as one of the reasons for not participating in physical education classes, may be related to the fact that in adolescence there are physical changes with sexual and hormonal characteristics present in this phase of development, as well as changes in body perception, which together, define body identity (Ferreira, 2013). The body image that the adolescent has of himself, can be negatively influenced by excessive concerns about his physical appearance, thus affecting the satisfaction that the adolescent has about his body, which is often linked to the ideals of beauty reflected by modern society (Ariza-Vargas, Salas-Morillas, López-Bedova \& Vernetta-Santa, 2021; Silva, Silveira, Machado, Haikal, Silva \& Silva, 2018; Teixeira, 2016). Studies point out that the continuous practice of physical exercise positively assists in the assessment of their own body image, and young people who do not have this habit, tend not to submit to any practice due to shame or dissatisfaction with their own body and the image they have of it, tending to show more sedentary behaviors and move away from activities that involve body movement (Ariza-Vargas, Salas-Morillas, López-Bedova \& Vernetta-Santa, 2021; Garrido, García, Flores \& Mier, 2012).

It should also be noted that in this phase it is common for students to face identity crises, conflict, and doubts, with an increase in shyness, fluctuations in self-esteem and shame in exposure to classmates (Moreira, Maciel, Nascimento \& Folle 2017). Therefore, these factors, as well as the rapid or slow development of young people, directly affect their selfconfidence, reflecting the non-participation in practical classes. Furthermore, there is a relationship with the level of motor skills among students, since in many cases physical education classes become the stage for the most skilled recreational activities, due to the lack of teacher planning, and thus the pedagogical elements end up distancing themselves from the objectives set (Pozzobon \& Folle, 2007).

Therefore, if the sports content is worked with a focus on competitive and physical fitness aspects, suppressing the playful, inclusive, and socializing activities, the situation can become worse, contextualizing a significant number of non-participation since the most skilled stand out at the expense of the least skilled (Evans, 2014). In this sense it is relevant to highlight that questions related to the methodological functioning are necessary, so that there is an identification of the students' interest in the contents taught, reducing the occurrence of dropping out of practices. Evasion, dropout, or demotivation in classes may also be related to the fact that the teacher privileges only sports modalities, developing in their classes a single content for a considerable period (Darido, 2000).

In this perspective, research indicates that physical education has not been developed according to what is determined by official curricula, such as the National Curriculum Parameters. That said, teachers do not use strategies that make students more interested in classes
(Freitas, Silva, Lacerda \& Leonardi, 2016).

Lack of motivation and disinterest end up affecting the teaching-learning process, and thus, without strengthening the process of changes that occur through learning, evasion becomes even more frequent (Mendes, 2013). Research shows that motivation is one of the main factors for student participation in physical education classes, with relevance in the development of learning and the performance of motor skills, as it has a significant role in the initiation, maintenance, and intensity of behavior (Franchin \& Barreto, 2006; Mendes, 2013; Garcia, Román-Palmero, García, Guillamón, Soto \& Cantó, 2019).

In view of the data presented by the current literature, our article seeks to find the main reasons for dropping out of school physical education classes, as well as expanding this knowledge so that the teachers responsible for the discipline identify themselves and search for the best ways in order to motivate their students. , especially in high school, either by understanding their reasons or the need for changes in their planning, thus helping to distance them from sedentary behaviors, demonstrating the importance of physical education classes for their personal training and improving the quality of life.

Having presented this initial scenario, this research sought to analyze the dynamics of physical education classes in the 3rd year of high school in public schools and to recognize the profile of the classes and the involvement of students, understanding the reasons that lead them to drop out of classes.

\section{Method}

This is a qualitative and quantitative investigation, which, according to Sampieri, Collado, and Lucio (2006) allows numerical measurement, while the qualitative focus refines the research questions, usually without numerical measurement, such as descriptions and observations. This is a descriptive study, in which the objective is to describe the facts and phenomena of a given reality (Triviños, 1987), and transversal, considering that the participants were consulted in a single moment. A questionnaire was used as an instrument to collect information, answered by 517 students (260 females and 257 males), from the 3rd year of high school, from eight state public schools in the interior of São Paulo. To compose the sample the municipality was divided by geographic region (north, south, east, and west) and schools were chosen for convenience (two from each region). For information analysis, descriptive analysis and content analysis were used.

The applied questionnaire, developed by the researchers and composed of 22 closed questions and 3 open questions, aimed to raise data regarding the participation of students in physical education classes, the contents and model of the classes, as well as the reasons why students do not participate in classes, including what they would change and the content they would like to have. For analysis of information, descriptive statistics (mean, standard deviation, median, mode, minimum and maximum, generated through the program / tool EXCEL 2013), were used, and for qualitative analysis, the software QSR Nvivo 10 was used, together 
with) were used, and content analysis comprised of preanalysis (organization), exploration of the material (coding) and treatment of the results obtained, followed by inference and interpretation of data (Bardin, 2011).

In the organization of the information, the responses provided by the participants were initially read and phrases and words were highlighted, adopting the rules for the selection of the content; exhaustiveness - encompasses the «totality of communication»; representativeness - relative to the universe; homogeneity - data similar to the themes; pertinence - adequacy to the content and objective of the research; and exclusivity - grouping of information in blocks with elements initially constituted by differentiation and then immediately by analogy.

The research project was approved by the Ethics Committee of the Sao Paulo State University Julio de Mesquita Filho by Opinion 1353569. Prior to the collection of information, permission was requested for the development of the research with the professional responsible for the participating schools; the Informed Consent Form was delivered to the participants, since the condition of participation in the research was the return of the Consent Form duly signed by the participant/guardian.

\section{Results}

A total of 517 high school students participated in the research, 260 of whom were female and 257 were male, aged between 17 and 18 years old, distributed in eight state public schools in the city of Bauru. We divided schools by geographic region, with 136 participants in the north (57 girls and 79 boys), 129 in the south ( 68 girls and 61 boys), in the east 118 participated ( 64 girls and 54 boys) and finally in the west, one total of 134 participants ( 71 girls and 63 boys). The schools were chosen for convenience according to the region of the city in which they are located, two from each region.

The 22 closed questions (referring to the level of participation, participation in the court and in the classroom, preferences and interests, content) were answered by the 517 participants, and the 3 open questions (directed to the reasons for dropout, which the students would change and content they would like to have) were answered by the 232 who, in the first question, mentioned not participating, or sometimes participating in physical education classes. This group represents $44 \%$ of the sample, being 173 girls and 59 boys. Of the 517 students participating in the sample, 68 replied that they did not participate in classes in the court (60 girls and 8 boys) and 164 responded that they sometimes participate (113 girls and 51 boys).

Figures 1 and 2 contain the answers to questions 13 to

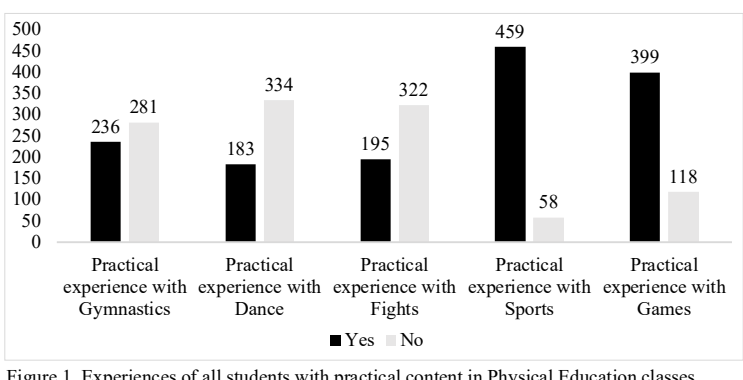

22 , related to the theoretical and practical content developed by teachers in physical education classes. In Figure 1, the highest incidence of responses for practical experiences with gymnastics, dance and fighting is «no», and «yes» for sports and games, while the data in Figure 2 demonstrate a greater number of theoretical experiences with these curricular contents (gymnastics, dance and fighting), with experiences with dance having the lowest incidence of responses.

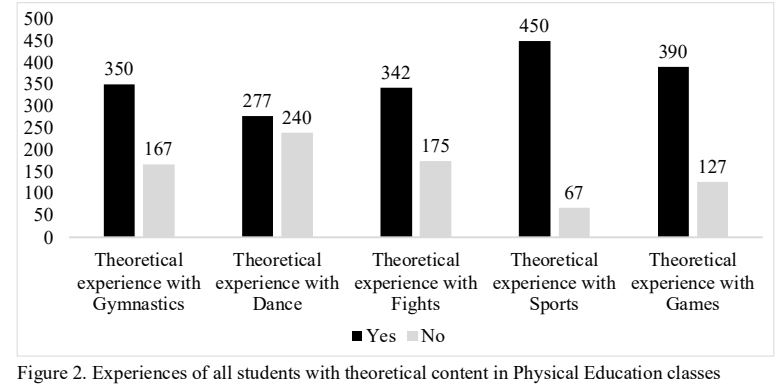

Regarding the theoretical and practical experiences of the students who answered «no» to participate or «sometimes» participate in the classes shown in Figure 3, most responded not having contact with the practice of gymnastics, dance and fighting, while a significant number claimed to have theoretical experiences with all subjects, with the exception of dance, in which most of the students answered that they had no experience with this content. Although 128 students answered that they had no theoretical experience with dance, the number of students who have this experience is large (104), higher than the number of students with practical experiences (62).

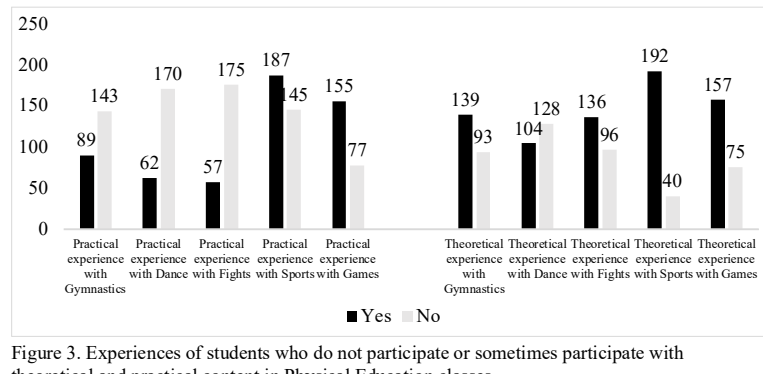

theoretical and practical content in Physical Education classes

To elaborate the three tables presented below, the answers to the three open questions were used, answered only by the students who declared not to participate or sometimes participate in the class. The tables were organized based on the thematic categories related to reasons for not participating in physical education classes, opinion on change in physical education classes and content students would like to have in physical education classes, generated by analysis of the content of the responses, based on the three stages proposed by Bardin (2011).

This phase led to the unification of the content and exploitation of the material from the reorganization of the registration units into thematic categories for the interpretation of the information in the database. The blocks with groupings of information were organized in units from three different actions: clipping (record units); enumeration (counting) and classification/aggregation (categories). The registration units, where the answers were organized in paragraphs, became key words and were grouped into three categories: Reasons for not participating in physical 
education classes; What would change in physical education classes; Content students would like to have in physical education classes, as shown in Tables 1,2 and 3 .

Table 1

\begin{tabular}{|c|c|}
\hline Registration Unit & Answers \\
\hline Interest & $\begin{array}{l}\text { (394) Because I don't want to; (225) I don't participate because I don't like } \\
\text { it; (341) I don't participate because I don't like physical education; (474) } \\
\text { Sometimes I do not participate, because it is not something that interests me }\end{array}$ \\
\hline Teacher & $\begin{array}{l}\text { (442) Sometimes the environment is not favorable, as students become } \\
\text { individualized and the teacher does not promote interaction in activities that } \\
\text { interest everyone; ( } 456 \text { ) Because the teacher does not spend anything on the } \\
\text { court and also does not stay in the classroom; (500) Because he doesn't let } \\
\text { people talk, gives his own opinion and is also boring and has nothing to do } \\
\text { with physical education. }\end{array}$ \\
\hline Content & $\begin{array}{l}\text { (169) Activities in my view are unnecessary; (83) I don't like anything that } \\
\text { involves a ball; (208) Because of some classes that I don't like very much; } \\
\text { (56) [...] because the teacher does nothing but soccer and volleyball; (55) I } \\
\text { do not participate because there is a table-tennis table, but the teacher never } \\
\text { releases. Only frees the court to be open and I hate to play sports; (63) } \\
\text { Because there is only soccer. }\end{array}$ \\
\hline Materials & $\begin{array}{l}\text { (220) I participate sometimes because the court has no structure for } \\
\text { students, only the soccer court; ( } 486 \text { ) In my opinion the problem is not in } \\
\text { class, but in the lack of material provided to us; }\end{array}$ \\
\hline Health & $\begin{array}{l}\text { (56) I do not participate because I have rhinitis and bronchitis [...]; (172) I } \\
\text { cannot do it because I have bone wear on my hip and because I have also } \\
\text { attested; ( } 401) \text { Because of my asthmatic bronchitis; (512) Because of a knee } \\
\text { problem I have. }\end{array}$ \\
\hline & (334) Sometimes I don't participate because [...] I am sedentary; (416) \\
\hline \multicolumn{2}{|c|}{$\begin{array}{c}\text { Sedentary Lifestyle Because I'm sleepy, not wanting to run around here and there; (338) } \\
\text { Because I am not a morning person and the classes are very boring. }\end{array}$} \\
\hline Other & $\begin{array}{l}\text { (72) Because it is not the last classes; ( } 80 \text { ) Because it is cold or raining; } \\
\text { (331) Sometimes I don't participate, because I have a more serious } \\
\text { commitment outside of school; ( } 399 \text { ) I don't participate in classes on the } \\
\text { court, because I leave school and go straight to work; (409) Because I keep } \\
\text { doing other things; (223) Because I use to go out of school because of my } \\
\text { religion, and I don't feel well; (417) Because no one else proposes, } \\
\text { especially girls, I like it, but playing alone is not enough. And there is no } \\
\text { way to play with the boys, because they will make fun of me for being a } \\
\text { girl; (204) Because I don't exercise and I don't have an affinity with the rest } \\
\text { of the class. }\end{array}$ \\
\hline
\end{tabular}

Table 2

What would change in physical education classes

Registration Unit

(56) Sports [...]; (63) Who had other activities; (129) The way to teach physical education is to educate the body with various games, sports etc., not to throw a ball on the court; (227) Sports and activities that everyone could participate in; (236) Sports that everyone interacts and participates in, not just soccer; (505) The contents.

(341) Take as a mandatory subject; (344) I would only do more activities forcing students to participate; (395) If everyone participated and if it was

Obligatoriness mandatory it would be better, but it is optional; (417) That girls were forced to do. At my old school we were obliged to play a little at least, because half of the grade was for participation.

(56) [...] the teacher's interaction with the students, because she doesn't even

Teacher watch; $(80,82,83,85)$ The teacher; $(84)$ The teacher, she does not teach a class that makes everyone participate; (99) The way the teacher does nothing.

(204) I would try to entertain students with group activities; (397) Inclusion of all students, plus sports and gymnastics; (485) [...] take more practical classes that involve everyone, not just soccer classes; (499) I would change more in the sports field because girls do not participate.

(483) More practical classes in the court; (442) Have more theoretical classes and greater interaction with students; (503) For more practical classes; (332) Higher frequency, 2 a week is little; (337) Only practical classes in the court, because most of the time the teacher lets the boys play soccer and the girls do nothing; (480) I would change just about everything, starting by taking theoretical things into practice; (55) Always release the table-tennis table; (67) More organization; (71) More organization and dense activities; (450) I would change the way of 'doing' sports; (410) I would divide the time, in one class the girls use the court, in the other the boys use it.

(59) I would not change anything, because you can choose what you want
boys use it. to do; $(60,492,496)$ Nothing; (500) Everything, because it is boring, the class gets boring; (504) Everything; (506) Everything, especially the class gets
teacher.

Table 3

Content students would like to have in physical education classes

Registration Unit

(395) Handball would be wonderful; (397) Fight, games and goalball class; (324) American football, some other fights and dance style; (67) More sports,

Sports because there is only soccer every class; (125) Varied sports; (63) That there was something other than soccer; (325) Classes that all students can participate! Not just soccer

Dance and Music (59) I think it would be cool if it had music, dance, etc.; (506) Dance classes; Dance and Music (209) Dances; (437) More dance.

Regarding the (512) On the human body, (501) [...] body movements, body evolution; (61) body Body, muscles [...]

Fights (489) Perhaps more about fights; (450) [...] more fights; (442) Fights, sports, Fights etc. [...]; (324) [...] some other fights [...]; (397) Fight class [...].

Games and (65) More content such as games [...]; (55) I wanted you to clear the table-

\begin{tabular}{ll} 
Playing tennis table; (99) Different games with the help of the teacher. \\
\hline (62) Gymnastics, sports [...]; (227) Fights and gymnastics; (228) Gymnastics,
\end{tabular}

Gymnastics fights and dance; (337) More gymnastics; (78) Flexion, rope, running, group work: (517) More practical functional exercise classes; (83) Stretching [ work; (517) More practical functional exercise classes; (83) Stretching [...].

Theoretical documentaries; (514) I like to delve into the various subjects that cover the

Contents world of sports, its history and the like [...]; (442) Fights, sports, etc. ..., more world of sports, its history and the
critical analysis on these subjects. (204) Classes different from traditional ones; (332) [...] more Brazilian

culture [...]; (424) Skate [...] ball, etc.; (417) [...] health classes; $(500)$ Physical education; (334) More practical activities; (495) [...] on drugs that
many use in gyms; (346) More free classes than theoretical classes.

\section{Discussion}

The present research had as main objective to understand the reasons that lead adolescents of the third year of high school, to abandon physical education classes. The initial results of the survey show that $44 \%$ of the sample has some barrier that prevents them from taking classes, of which 74.6 $\%$ are girls, and consequently this majority answered the open questions about non-participation. In this sense, it is noticed that the physical education curricular component has its own characteristic, moments of bodily enjoyment beyond the classrooms, making students' lack of interest and lack of participation something easily located and explicit, different from other curricular components, in which this disinterest is mitigated in the classroom desks (Millen Neto, Cruz, Salgado, Chrispino \& Soares, 2010).

The dissatisfaction of an adolescent with a physical education class is a reflection of the cultural, educational and political issues of our time and is in line with the prospect presented by Hallal (2012), when describing that physical inactivity increases with age, being higher among females, higher in developed countries, and has a significant increase in developing countries, such as Brazil.

In this sense, Delgado, Paranhos and Vianna (2010) present in their study, that in private schools there is a greater participation of girls in physical education classes when compared to public schools. The authors justify this fact, because the context experienced by girls from private school, may provide more incentive for parents to practice sports since early childhood, which does not usually happen with students from public schools. They also point out that physical education classes in public schools are more important for these students than in private ones.

In addition, it is worth noting that the practice of sports can be seen exclusively by girls and less skilled students even in the school context. Therefore, it is common for those who already practice a sport outside the school, to show greater motivation to participate in classes (Delgado, Paranhos \& Vianna, 2010). This fact reinforces the idea that school physical education has become a space for the expression of skills and reproduction of asymmetric relations between gender, and consequently, a space for selection and exclusion (Brandolin, 2015).

Starting from this relationship between disinterest that leads to non-participation, through the reports presented in our results, Darido (2004) brings in his research data that corroborates ours, regarding students who do not practice physical education classes. The author concludes that there is a gradual withdrawal of students from the practice of physical education at school, particularly in high school, and also outside of school, one of its triggering factors being the repetition and similarity of the contents of physical education classes in elementary and high school. Such programs, roughly speaking, would be restricted to the execution of technical sports gestures.

The results presented here on the frequency of theoretical and practical experiences, occur in the following order: sports, games, gymnastics, fight, and dance, with sport being the most frequent and most criticized content in the reports of dissatisfied students. This can be seen in students' 
responses to activities they would like to perform in class, such as varied sports that are not class content or criticisms related to classes in which sport predominates, such as football.

This influence of sport in physical education classes is debated by the National Curriculum Parameters (Brasil, 2000), as being «of such magnitude that we do not have school sports, but sports at school» (p.34). In this recurrence, being unskilled puts the student into a condition of passive spectator and with low perception of self-efficacy, something with a profound biopsychosocial outline, mediated by the lack of didactic transposition of contents that provoke significant learning and that provide opportunities between students and the object of reciprocity relationship knowledge, as shown by the students' statements presented in the Tables.

Thus, the participation of students in planning and choosing content can be an essential stimulus to promote interest and motivation. Therefore, making the student the protagonist of the choice of the content they want to learn, improving their knowledge and taking pleasure in participating, can be a viable and beneficial way to reduce the demotivation in physical education classes (Merida, Rodrigues, Grillo \& Souza, 2006; Viana, Souza \& Reis, 2015; Carraça, 2017).

Starting with the analysis of the interest category, disliking classes is the predominant reason for not participating. According to the Law of Guidelines and Bases no 9394/96 (Brasil, 1996), in the educational context it is illegitimate not to participate, or to be exempt from a certain curricular component. Thus, non-participation is often justified by students due to their commitments or work outside of school and after class, which show to be recurrent mainly in physical education classes (Darido, 2004)

The specific purposes of secondary education are to consolidate and deepen the knowledge acquired in elementary education; the continuation of studies; preparation for work and citizenship; the development of skills such as continuing to learn and the ability to adapt flexibly to new conditions of occupation and improvement; the improvement of the student as a human being, including ethical training and the development of intellectual autonomy and critical thinking; and the understanding of the scientifictechnological foundations of production processes, relating theory and practice (Brasil, 2015, p.33). However, the reports referring to the obligation, for example, express the lack of legitimacy of these curricular components and teaching practice, reinforcing the need to contextualize their content in order to articulate the area's competences with the objectives of high school (Furtado \& Borges, 2020).

The meta-analysis on the determinants of physical activity, by Bauman, Sallis, Reis and Wells (2012), highlights the valuable aspect of school and community initiatives that promote physical, mental, social, and spiritual health through psychological factors, particularly self-efficacy, and cultural and social factors such as family and social support. These determinants can explain the reports that aim for greater «interaction», «fit», «inclusion», and «integration», needs inherent to the human being and specifically valued during the period of adolescence, a phase in which interpersonal attributes and social skills influence their interactions with others in the formation of their self-esteem, considered an important aspect of quality of life and mental well-being, since it relates to satisfaction, independence, adaptability, leadership, resilience to stress and high levels of achievement (Fox, 1997).

Therefore, for the integral development of the adolescent, it is important that the teacher understands these aspects, as well as the physical and cultural transformations present, which are also responsible for growth and motor development in this age group. That said, sports participation is relevant to the stage, above all, it requires competent leadership that values appropriate and varied experiences for good development. (Gallahue, Ozmun \& Goodway, 2013).

The category Teacher is reported both for the reasons that make students not participate, and in the spheres that would change in physical education classes, «[...] sometimes the environment is not favorable, because students are individualized and the teacher does not promote interaction in activities that interest everyone «(student 442); «Only practical classes in the court, because most of the time the teacher lets the boys play soccer and the girls do nothing») (student 337); «I would change more in the sports area because girls do not participate» (student 499), these are examples that added to the fact that the prevalence of physical inactivity is higher among girls, fosters the need to rethink pedagogical studies on physical education in in order to understand the students' culture and what goes on at school (Millen Neto et al, 2010), as pointed out by the research by Alberto and Figueira Junior (2016), who found a relationship between the lack of stimulation of the physical education teacher and insufficient levels of physical activity in adolescent girls.

Guedes (1999 p.10), in his proposal for health education, revisits the history that various methodologies attribute to the physical education teacher:

[...] the supporting role of the educational process, responsible simply for entertaining children and young people through the so-called recreational activities, for organizing and accompanying commemorative activities, for guiding physical exercises, etc.; instead of developing a set of content that can truly contribute in a broader educational context, to the education of students.

The results indicate that the teachers' overvaluation in relation to sports and games occurs both in the court and in theoretical classes, a moment that it would be opportune to develop content that perhaps did not have as much practical experience. Such an event Darido (2004) attributes to the rooting of certain activities and difficulties in reflecting and modifying such procedures; for this, a new behavior on the part of teachers is required, requiring training of greater academic consistency (Guedes, 1999).

The result presented here brings systematic criticism to the number of classes in which there is a predominance of sports; however, it shows a survey of the demand for other elements such as games, gymnastics, fighting, dancing, content concerning the human body, functional exercises, health, and culture. Thus, it is believed that Physical Education needs to find its value at school so that it reaches the same level of importance as other disciplines. For this, 
teachers must develop content that reaches the «social, economic, political, biological and body practices developed during classes» (Souza, Silva, Maldonado, 2017, p.65).

Diversity is a widely discussed topic and influences the school space itself, given this context, high school tends to seek its own identity and form a more flexible curriculum, which matches the language of young people, in order to understand the student himself and school diversity itself (Bungenstab, 2019).

In order to affirm values and identities, body culture must seek reflections on the many ways of representing the world that man produces throughout his history, through the varied contents offered by the forms of body expressions (Castellani Filho, Lúcia, Taffarel, Varjal \& Escobar, 2014). In this sense, Castellani et al (2014) also emphasize that the formation of conscience depends on the construction of identity and values, aiming at education and social transformation. It is believed, therefore, in the need for the contents of the classes to take students to social reflection, to overcome common sense, through critical and emancipated thinking about their own body culture.

Therefore, this proposal with a cultural bias for Physical Education in Schools aims to form critical citizens capable of reproducing and above all, transforming their culture, locating in the body culture the benefits and possibilities of communication, expression of feelings and emotions, as well as leisure and health. Thus, during the development of the discipline in schools, the students will be able to develop their potential as a citizen and human being, in a democratic way, leading also to discuss the great Brazilian social problems (Darido, 2001).

In particular, health-related content comes close to that proposed in official documents such as National Curriculum Parameters (Brasil, 2000) and Common Curricular National Base (Brasil, 2017), with a view to developing a foundation for the principles related to working with physical activity focused on health at school, through teaching strategies that contemplate not only the practical aspect, but above all the approach to concepts and principles that provide subsidies to students to adopt healthy habits beyond the period of schooling.

Some authors also believe that the motivation to practice in physical education classes may be associated with the skills that some students already have due to the practice of sports and other activities outside the school environment, indicating even greater satisfaction in classes (Carraça, 2017).

For Taylor, Ntoumanis and Standage (2008), relationships can significantly influence the participation and autonomy of students at school, therefore it is necessary that the teacher encourage them to generate improvements in the social context and courses during classes, as it can be valuable contribution to the maintenance of the psychological needs of students. Thus, Silva and Bracht $(2012$, p.90) emphasize that it is up to the teacher to prioritize «dimensions such as that of affection, learning and not mandatory without meaning for the student».

It should be noted that the perception of high school students brings positive elements, capable of improving the dynamics of the classes, from dialogue and affection towards the teacher, to factors such as their own discipline and the ideal time for students to be fluent (Medeiros Filho, Oliveira, Sousa, Tahim, Alves Junior, Sousa \& Pontes Junior, 2016). The negative aspects of the classes can be evidenced by Silva and Bracht (2012) as lack of materials and school infrastructure, which are aspects that need to be highlighted and that influence the participation of the classes. Thus, for the teacher to act in a motivating manner, it is necessary that he also be motivated and recognized professionally, through «truly continuous training processes and decent salaries, they can help in building motivations for the development of the work» (Silva \& Bracht, 2012, p.92).

Silva and Bracht (2012) believe that motivation is related to the innovation of professional practice, therefore, innovative teachers tend to present a relationship between their life history and their professional career. Innovative teachers seem to be more concerned with the influence of their classes on the lives of their students and with the recognition of their performance. The authors also point out that although the use of professional experiences is important to promote innovative classes, there is also a need for greater openness for exchanging educational practices among peers in education networks.

It can be suggested that the positive perception and motivation of high school students for physical education classes is also related to the change in the environment, which is often different from the ordinary classroom, reaching even students who do not have regular participation or identification with sports and physical activities. Therefore, physical education classes should provide skills learning, satisfaction, and development on an equal basis for all students. (Brandolin, Koslinski \& Soares, 2015; Carraça, 2017). In addition, factors such as organization and consistent planning of classes are believed to be motivating students (Brandolin, Koslinski \& Soares, 2015; Carraça, 2017; Costa, Flores, Andrade, Anversa \& Souza, 2018).

Finally, it is understood that the information presented here provides subsidies to broaden the debate on the subject, which is of fundamental importance for the area. On the other hand, it is understood that the research has limits, since it discusses the reality of part of the students of high schools in a municipality in the state of São Paulo and, therefore, expand the research to other regions of the state and of the country could bring new answers to the problem presented. In addition, the focus of the analysis was based on the demotivation expressed by the students interviewed, not addressing factors related to what motivates them for the class. In this sense, it is understood as important for future research the inclusion of topics such as youth cultures, biological and social factors in the relationship with physical education classes, leading to a greater understanding regarding the psychological/emotional, cultural and physiological influences, as well as the relationship with the motivation/demotivation of students for physical education classes.

\section{Conclusions}

Through the data and analysis presented, it was found that approximately half of the participating students, mainly girls, participate little, or do not participate in physical 
education classes, this result being related to the methodology and the selection of content developed by the teacher.

When knowing the prospect of increasing physical inactivity in contemporary society, it becomes essential to know and deal with the impediments of physical activity practices, being imperative to disconnect the school space from the reproduction of sports fundamentals that are repeated since elementary school.

The educational nature of sport must be present at school, as well as other body culture contents, in a theoretical and practical balance of contextualized physical education, through education aimed at collective health, which meets all students, respecting their differences, stimulating their potential to contribute so that they are proactive, critical, and autonomous in relation to their health and quality of life.

\section{Disclosure statement}

No potential conflict of interest was reported by the author(s).

\section{References}

Alberto, Á. A. D., \& Júnior, A. J. F. (2016). Prevalência de inatividade física em adolescentes e sua associação com variáveis socioculturais. Pensar a Prática, 19(4), p. 800813. https://doi.org/10.5216/rpp.v19i4.35317

Ariza-Vargas, L., Salas-Morillas, A., López-Bedoya, J., \& Vernetta-Santana, M. (2021). Percepción de la imagen corporal en adolescentes practicantes y no practicantes de gimnasia acrobática. Retos, (39), 71-77.

Bardin, Laurence. Análise de conteúdo (Edições 70). Lisboa: Portugal, 2011.

Bauman, A. E., Reis, R. S., Sallis, J. F., Wells, J. C., Loos, R. J., Martin, B. W., \& Lancet Physical Activity Series Working Group. (2012). Correlates of physical activity: why are some people physically active and others not?. The lancet, 380(9838), 258-271. https://doi.org/10.1016/S01406736(12)60735-1

Brandolin, F., Koslinski, M., \& Soares, A. J. G. (2015). A percepção dos alunos sobre a educação física no ensino médio. Journal of Physical Education, 26(4), 601-610. https://doi.org/10.4025/reveducfis.v26i4.29836

Brasil, L. D. B. (2015). Lei 9394/96-Lei de Diretrizes e Bases da Educação Nacional.

Brasil. Ministério da Educação. Secretaria de Educação Média e Tecnológica. (2000). Parâmetros curriculares nacionaisPCN: ensino médio: ciências humanas e suas tecnologias. MEC/SEMT.

Brasil. Ministério da Educação. Base Nacional Comum Curricular. Versão definitiva. Brasília: MEC (2017).

Brasil. Lei de Diretrizes e Bases da Educação Nacional. Lei 9.394/96. Brasília: 1996. 2a ed. Atualizada em junho de 2018.

Bungenstab, G. C. (2019). Educação Física, ensino médio e juventude: vamos falar sobre crise? Pensar a Prática, 22(53197), 1-10.

Carraça, E. V. (2017). Um modelo motivacional do envolvimento dos jovens nas aulas de educação física.
Retos: nuevas tendencias en educación física, deporte y recreación, (31), 282-291.

Castellani Filho, L., Lúcia, S. C., Taffarel, C. N. Z., Varjal, E., Escobar, M. O., \& Bracht, V. (2014). Metodologia do ensino de educação física. Cortez Editora.

Cedran, P. C., de Martins, C. M. D. C., \& Ligeiro, D. C. (2016). Motivação na educação física escolar: relatos da prática docente junto aos alunos da $3^{\mathrm{a}}$ série do ensino médio da rede estadual paulista. Revista Ibero-Americana de Estudos em Educação, 11(25), 395-405.

Christofaro, D. G. D., De Andrade, S. M., Mesas, A. E., Fernandes, R. A., \& Farias Junior, J. C. (2016). Higher screen time is associated with overweight, poor dietary habits and physical inactivity in Brazilian adolescents, mainly among girls. European journal of sport science, 16(4), 498-506.

Colunga-Rodríguez, B. A., Ángel-González, M., VázquezJuárez, C. L., Vázquez-Colunga, J. C., Castellanos-Ángeles, R., Colunga-Rodriguez, C., \& Picazo, G. D. (2020). Motivos para la Práctica del Ejercicio Físico en Estudiantes de Secundaria. Retos, 38(38), 89-94.

Costa, L. C. A. D., Flores, P. P., Andrade, N. D. P., Anversa, A. L. B., \& Souza, V. D. F. M. D. (2018). Tecendo relações entre a motivação para as aulas de educação física e o Ideb. Revista Brasileira de Ciências do Esporte, 40(4), 370-373.

Darido, S. C., \& Rangel, I. C. A. (2000). Educação Física Na Escola: Implicações Para a Prática Pedagógica . Grupo Gen-Guanabara Koogan.

Darido, S. C. (2004). A educação física na escola e o processo de formação dos não praticantes de atividade física. Revista brasileira de educação física e esporte, 18(1), 6180. https://doi.org/10.1590/S1807-55092004000100006

Delgado, D. M., Paranhos, T. L., \& Vianna, J. A. (2010). Educação Física escolar: a participação das alunas no ensino médio. Efdeportes, Buenos Aires, 14(140).

Evans, J. (2014). Equity and inclusion in physical education PLC. European physical education review, 20(3), 319334. https://doi.org/10.1177/1356336X14524854

Ferreira, A. A., Nogueira, J. D., Wiggers, I., \& Fontana, K. E. (2013). Composição e percepção corporal de adolescentes de escolas públicas. Motricidade, 9(3), 19-29.

Franchin, F., \& Barreto, S. M. G. (2006). Motivação nas aulas de educação física: um enfoque no ensino médio. I Seminário de estudos em Educação Física escolar, 2012, 1-33.

Freitas, J. F., da Silva, J. E. B., Lacerda, M. R. A., \& Leonardi, T. J. (2016). A identidade da Educação Física escolar sob o olhar dos alunos do $5^{\mathrm{a}}$ ano do ensino fundamental I. Pensar a Prática, 19(2). https://doi.org/10.5216/ rpp.v19i2.39482

Fox, K. R. (1997). The physical self and processes in selfesteem development.

Furtado, R. S., \& Borges, C. N. F. (2020). Educação física escolar, legitimidade e escolarização. Humanidades \& Inovação, 7(10), 24-38.

Garcia, J. E. M., Palmero, J. R., García, S. L., Guillamón,A. R., Soto, J. J. P., \& Cantó, E. G. (2019). Propiedades psicométricas de la Escala de Motivación Deportiva y análisis de la motivación en las clases de educación físi- 
ca y su relación con nivel de práctica de actividad física extraescolar. Retos: nuevas tendencias en educación física, deporte y recreación, (36), 283-289.

Garrido, R. E. R., García, A. V., Flores, J. L. P., \& de Mier, R. J. R. (2012). Actividad físico deportiva, autoconcepto físico y bienestar psicológico en la adolescencia. Retos: nuevas tendencias en educación física, deporte y recreación, (22), 19-23.

Gallahue, D. L., Ozmun, J. C., \& Goodway, J. D. (2013). Compreendendo o desenvolvimento motor-: bebês, crianças, adolescentes e adultos. AMGH Editora.

Guedes, D. P. (1999). Educação para a saúde mediante programas de educação física escolar. Motriz, 5(1), 10-14.

Hallal, P. C., Bauman, A. E., Heath, G. W., Kohl 3rd, H. W., Lee, I. M., \& Pratt, M. (2012). Physical activity: more of the same is not enough. The Lancet, 380(9838), 190-191. http://dx.doi.org/10.1016/S0140-6736(12)61027-7

Lourenço, C. L. M., Zanetti, H. R., dos Santos Amorim, P. R., Mota, J.A. P. S., \& Mendes, E. L. (2018). Comportamento sedentário em adolescentes: prevalência e fatores associados. Revista Brasileira de Ciência e Movimento, 26(3), 23-32.

Lucena, J. M. S., Cheng, L.A., Cavalcante, T. L. M., da Silva, V.A., \& de Farias Júnior, J. C. (2015). Prevalência de tempo excessivo de tela e fatores associados em adolescentes. Revista Paulista de Pediatria, 33(4), 407-414.

Martins, A. B. R., \& dos Santos Freire, E. (2013). O envolvimento dos alunos nas aulas de educação física: um estudo de caso. Pensar a prática, 16(3). https:// doi.org/10.5216/rpp.v16i3.19222

Medeiros Filho, A. E. C., Oliveira, K. B. B., Sousa, L. A., Tahim, A. P. V. O., Alves Junior, T. A., Sousa, F. C. S., \& Pontes Junior, J. A. F. (2016). Percepção discente sobre os fatores do processo de ensino-aprendizagem das aulas de educação física. Coleção Pesquisa em Educação Física, 15(2), 161-168.

Mendes, M. S. (2013). Da inclusão à evasão escolar: o papel da motivação no ensino médio. Estudos de Psicologia (Campinas), 30(2), 261-265. https://doi.org/10.1590/ S0103-166X2013000200012

Merida, M., Rodrigues, G. M., Grillo, D. E., \& de Souza, J. X. (2006). Educação física no ensino médio: motivos que levam as alunas a não gostarem de participar das aulas. Revista Mackenzie de Educação Física e Esporte, 5(2).

Millen Neto, A. R., da Cruz, R. P., da Silva Salgado, S., Chrispino, R. F., \& Soares, A. J. G. (2010). Evasão escolar e o desinteresse dos alunos nas aulas de Educação Física. Pensar a Prática, 13(2). https://doi.org/10.5216/ rpp.v13i2.7559

Moreira, C. H., Maciel, L. F. P., do Nascimento, R. K., \& Folle, A. (2017). Motivação de estudantes nas aulas de educação física: um estudo de revisão. Corpoconsciência, 21(2), 67-79.

Munaro, H. L. R., Silva, D. A. S., \& Lopes, A. D. S. (2016). Prevalência de tempo excessivo de tela e fatores associados em escolares de uma cidade do nordeste. $J$ Hum Growth Dev, 26(3), 360-367.

Peykari, N., Eftekhari, M. B., Tehrani, F. R., Afzali, H. M., Hejazi, F., Atoofi, M. K. \& Djalalinia, S. (2015).
Promotingphysical activity participation among adolescents: Thebarriers and the suggestions. International Journal of Preventive Medicine, 6(12). doi. 10.4103/2008-7802.151820.

Pozzobon, M. E., \& Folle, A. (2007). Motivação nas aulas de jogos esportivos no contexto escolar. Reescrevendo a educação. Chapecó: Sinproeste, 109-128.

Rodríguez-Rodríguez, F. J., Gatica, C. C., de la Rosa, F. J. B., \& Flores, A. A. A. (2017). Evaluación de la educación física escolar en Enseñanza Secundaria (evaluation of physical education in secondary school). Retos, (31), 76-81.

Sampieri, R. H., Collado, C. F., Lucio, P. B., Valencia, S. M., \& Torres, C. P. M. (2006). Metodología de la investigación. México, DF: Mcgraw-hill.

Silva, M. S., \& Bracht, V. (2012). Na pista de práticas e professores inovadores na educação física escolar. Kinesis, 30(1).

Silva, N., Silveira, M. F., Machado, I. C., Haikal, D. S. A., Silva, C. S. O., \& Silva, R. R. V. (2018). Auto imagem e satisfação corporal em adolescentes escolares. RBONE-Revista Brasileira de Obesidade, Nutrição e Emagrecimento, 12(75), 948-953.

Sousa, C. A., da Silva, P. A., \& Maldonado, D. T. (2017). Muito além da prática pela prática: educação física como componente curricular da educação básica. Cadernos de Formação RBCE, 8(1).

Taylor, I. M., Ntoumanis, N., \& Standage, M. (2008). A selfdetermination theory approach to understanding the antecedents of teachers' motivational strategies in physical education. Journal of sport and exercise psychology, 30(1), 75-94.

Teixeira, C. S. (2016). Estado nutricional de adolescentes: percepção da autoimagem e riscos de transtornos alimentares. (Dissertação de Mestrado). FAMERP, São José do Rio Preto.

Trivisios, A. N. (1987). Introdução à pesquisa em ciências sociais. São Paulo: Atlas.

Vianna, J.A., Souza, S. M. D., \& Reis, K. P. D. (2015). Bullying nas aulas de Educação Física: a percepção dos alunos no Ensino Médio. Ensaio: avaliação e políticas públicas em educação, 23(86), 73-93.

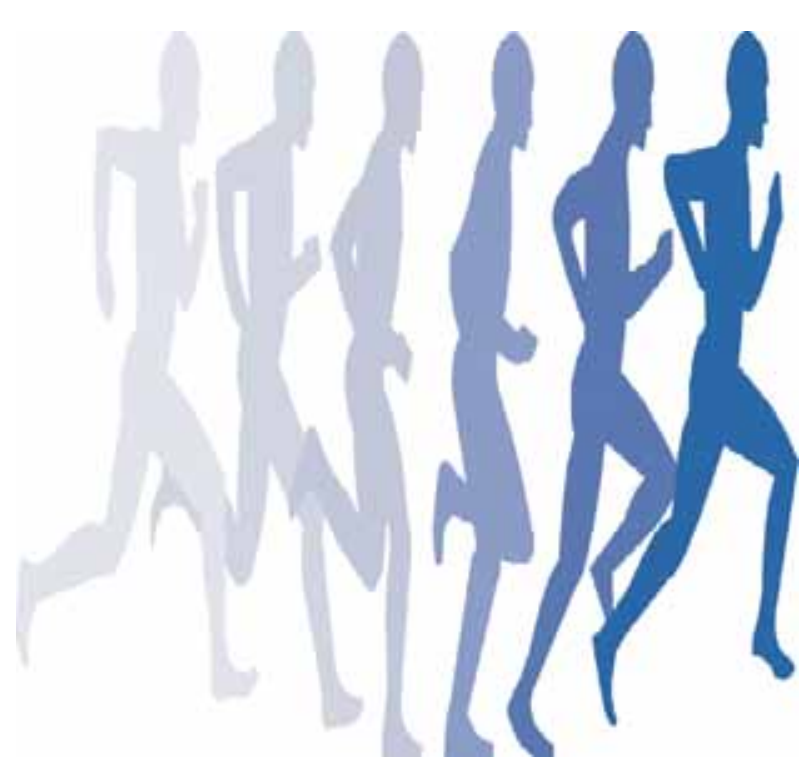

